УДК 378.4:61:68

\title{
ПЕРСПЕКТИВИ ВИКОРИСТАННЯ СУЧАСНИХ КОМП'ЮТЕРНИХ ТЕХНОЛОГІЙ ПРИ КРЕДИТНО-МОДУЛЬНІЙ СИСТЕМІ НАВЧАННЯ
}

\author{
С. Г. Гривенко, Ю. Г. Барановський
}

Кримський державний медичний університет імені С. І. Георгієвського

\section{THE PROSPECTS OF USING UP-TO-DATE COMPUTER TECHNOLOGIES IN CREDIT-MODULAR EDUCATIONAL SYSTEM}

\author{
S. H. Hryvenko, Yu. H. Baranovskyi \\ Crimean State Medical University by S. I. Heorhiyevskyi
}

\begin{abstract}
У статті розглядаються можливості використання сучасних комп'ютерних технологій у навчальному процесі. Вони полягають у використанні неттопів при створенні комп'ютерних класів. Залучення інноваційних технологій контролю та викладання дозволить оптимізувати навчальний процес, об' єктивізувати оцінювання студентів та зменшити енерговитрати більше ніж у 5 разів у порівнянні з “класичними” комп”ютерними класами.
\end{abstract}

The opportunities of using up-to-date computer technologies in educational process are considered in the article. They consist in using of nettops to set up computer classes. The attraction of innovative technologies for control and teaching will enable to optimize training, make objective evaluation of students and reduce the power consumption more than in five times compared to the 'classical' computer classes.

Вступ. Реформування вищої медичної освіти в Україні на засадах Болонськоїдекларації має на меті привести рівень підготовки лікарів у відповідність до європейських критеріїв. На сьогодні стає цілком очевидним той факт, що система традиційної організації процесу навчання у вищих медичних закладах України маєцілий ряд сугтєвих недоліків і потребує значного реформування. Хоча впродовж останніх десятиріч суттєво змінилася технологія навчального процесу івсеширше впроваджуються нові технічні засоби навчання та інформаційні комп'ютерні технології, протеякість підготовки лікарів не відповідає вимогам Болонської декларації. 3 цих позицій пошук нових підходів в оптимізаціїнавчального процесу безперечно $€$ актуальним [1].

Основна частина. Розвиток сучасного суспільства характеризується впровадженням у всі сфери діяльності людини інформаційних та комунікаційних технологій. Природно, що у сфері освіти комп'ютерні технології стали обов' язковим компонентом педагогічного процесу, запровадивши нові підходи до викладу і вивчення навчальних матеріалів, а також доступу до міжнародних та національних освітніх ресурсів колективного використання [6].

При переході вузів України на кредитно-модульну систему навчання значно збільшилась кількість контрольних заходів, відповідно збільшилось і наванта- ження на викладачів, що не може не призвести до зниження якості контролю успішності. Виходом із даної ситуації є застосування комп'ютерного обладнання та спеціального програмного забезпечення для автоматичного контролю знань студентів [4]. Основними напрямками інноваційних технологій є збільшення питомої ваги самостійної позааудиторної роботи студентів, комп'ютеризація та застосування сучасних засобів контролю знань із використанням рейтингової системи оцінювання рівня знань [3].

Проте перевірка знань студентів повинна здійснюватись об' єктивно і швидко, охоплювати весь матеріал навчального курсу, давати результат оцінювання 3 чітким розмежуванням для кожного студента, використовуючи однаковий матеріал і однакові умови процедури тестування. Об'єктивність оцінювання, як відомо, створює більш позитивний стимулювальний вплив на пізнавальну діяльність студентів. Найбільше цим вимогам відповідає комп'ютерне тестування, під час проведення якого виключається негативний вплив на результати тестування таких факторів, як настрій, рівень кваліфікації й інші характеристики викладача [5]. В той же час, об' єктивізація оцінювання знань студентів $є$ однією 3 найбільш вагомих переваг модульногопринципуорганізаціїнавчальногопроцесу. Щоденне бальне оцінювання рівня підготовленості студентів 
та високий рівень навчальної активності протягом заняття гарантує об' єктивність оцінювання та мотиваційну зацікавленість студента в його результатах. Досягти цього можна залученням стандартизованих занять, зокрема тестів, що є кроком не тільки до зазначеної вище необхідної складової навчального процесу, а ще й вагомим важелем підготовки студентів до майбутніх стандартизованих державних тестів формату “Крок” [2].

В останні декілька років на ринку IT технологій з' явились неттопи. Неттоп - це надкомпактний, енергоощадний та абсолютно безшумний комп'ютер (рис. 1).

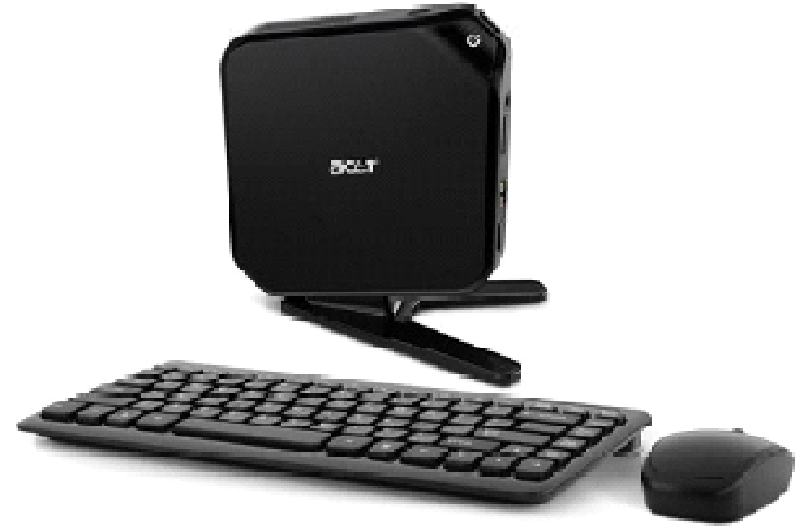

Puc. 1. Зовнішній вигляд неттопу.

Він ідеально підходить як для використання на роботі, так і вдома. Використовуючи неттопи, можливо створити ідеально тихий комп'ютер 3 енерговитратами та електромагнітним опроміненням в 4-6 разів нижче, ніж при використанні стандартних ПК. Цекрім значної економії заощаджень також покращує всі показники безпеки робочих місць. 3 неттопоми офіс (клас) буде позбавлений набридливого шуму куллерів, звільниться багато вільного місця на робочому місці та з'явиться значна економія на рахунках за електроенергію. Весь неттоп займає на столі стільки ж місця, скільки і звичайний рідкокристалічний монітор, оскільки він кріпиться до зовнішньої сторони монітора (рис. 2).

Енерговитрачання неттопу не перевищує 60 Вт, що більш ніж в 5 разів економніше, ніж у стандартного персонального комп'ютера. Якщо врахувати, що середній комп'ютерний клас складається не менше ніж

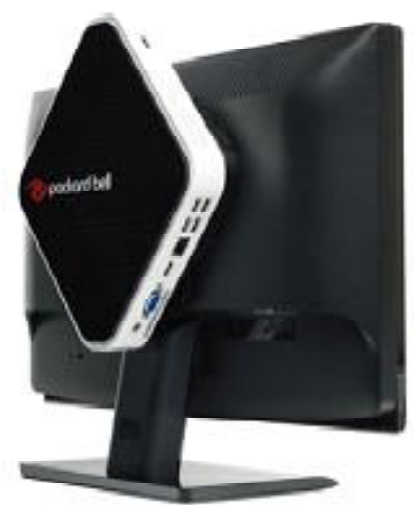

Puc. 2. Неттоп на зовнішній стороні монітора.

з 10 персональних комп'ютерів, то економія енерговитрат складе понад 2,4 кВт! В умовах фінансової кризи та постійного здорожчання енергоносіїв - це не останній аргумент на користь неттопів. Всі неттопи, які сьогодні наявні на ринку, абсолютно безшумні, тому що не мають жодного вентилятора та оснащені надтихим жорстким диском. Все це створює ідеальні умови для роботи студента за комп'ютером. 3 неттопом можливо комфортно працювати в будь-яких офісних програмах, використовувати всі можливості інтернету, переглядати фільми, слухати лекції та багатоіншого. Наявність великої кількості USB портів та WiFi 3'єднань дозволяє при створенні комп' ютерних класів на основі неттопів взагалі відмовитись від дротових 3'єднань для USB-slim-клавіатури, USB-мишки та створення локальної мережі і доступу до інтернету. Завдяки низьким енерговитратам, відсутності куллерів i т. п. неттопи не іонізують повітря, не накопичують пил, не створюють шкідливого для здоров’ я електромагнітного поля, тим самим підтримуючи комфортні умови для роботи студентів та відпочинку за ПК.

Висновок. Залучення інноваційних комп'ютерних технологій на основі неттопів дозволить оптимізувати навчальний процес та створити комфортні умови для навчання студентів. Використання комп'ютерних класів на основі неттопів буде сприяти зменшенню енерговитрат більше ніж у 5 разів у порівнянні 3 “класичними” комп’ютерними класами.

\section{Лiтература}

1. Волосовець О. П. Питання якості освіти уконтексті впровадження засад Болонської декларації увищій медичнійшколі /О. П. Волосовець// Медична освіта. -2005. -№2. - С. 12-16.

2. Стандартизований контроль у системі кредитно-модульного навчання / І. В. Завгородній, Л. Г. Шаповал, Н. М. Ткачук, О. В. Шаповал // Матеріали Всеукраїнської навчально-наукової конференції “Проблеми інтеграції ук-

раїнської медичної освіти у світовий освітній простір". Тернопіль: Укрмедкнига, 2009. -С. 87-88.

3. Климнюк С. І. Оцінка ефективності електронного навчання студентів і його методичне забезпечення / Климнюк С. І., Ткачук Н. І., Романюк Л. Б. // Матеріали Всеукраїнської навчально-наукової конференції "Проблеми інтеграції української медичної освіти у світовий освітній 